M.C. Castro and M.C. Langer - The mammalian fauna of Abismo Iguatemi, southeastern Brazil. Journal of Cave and Karst Studies, v. 73 , no. 2, p. 83-92. DOI: $10.4311 /$ jcks 2010 pa0140

\title{
THE MAMMALIAN FAUNA OF ABISMO IGUATEMI, SOUTHEASTERN BRAZIL
}

\author{
Mariela C. Castro and Max C. Langer \\ Biology Department, FFCLRP, University of São Paulo, Av. Bandeirantes, 3900, 14040-901, Ribeirão Preto, SP, Brazil, \\ marielaccastro@yahoo.com.br; mclanger@ffclrp.usp.br
}

\begin{abstract}
The Quaternary vertebrate fauna record of South America is characterized by the predominance of mammals, and the study of cave deposits can provide important information on their diversity and distribution. In Brazil, cave deposits have preserved remarkable fossil remains, including both large and small vertebrates, although the former have been the focus of most paleontological works. The fossils studied here came from Abismo Iguatemi, a karstic fissure located in the municipality of Apiaí, upper Ribeira River valley, São Paulo, Brazil. Blocks of sediment collected from its floor yielded a large sample of micro-remains, mainly composed of fragmentary small vertebrate specimens. Taphonomic parameters suggest that the fossil elements entered the cave either by entrapment or transported by rain runoff, as partially decayed carcasses or isolated elements. A total of 35 taxa were recorded in Abismo Iguatemi, four of which are extinct. The number of identified specimens per taxon (NISP index) is the best estimator of number of individuals at the burial site. The comparison of this fauna to that of other Quaternary deposits and to the present biodiversity of different areas reveals low similarity. The identification of fossil organisms with different ecological requirements (extinct savannah organisms and extant dense-forest organisms) suggests the existence of time averaging and may reflect environmental changes in the vicinity of the cave during the late Pleistocene and Holocene.
\end{abstract}

\section{INTRODUCTION}

The abundance and diversity of mammals, including the megafauna, is remarkable in the Quaternary fossil record of South America. Important information on the mammalian diversity can be obtained through the study of cave deposits. Caves sometimes act as natural traps for living animals and burial sites for organic remains. These are often protected from the normal processes of disintegration, such as scavenging, erosion, and fluvial transportation (Behrensmeyer and Hook, 1992). In the cave deposits, reworking and redeposition of skeletal remains by floods (Salles et al., 1999) and other fluvial activity (Sutcliffe, 1970) are common. The reliability of fossil deposits can be estimated by their completeness and by temporal or spatial averaging (Behrensmeyer and Kidwell, 1985; Behrensmeyer and Hook, 1992; Behrensmeyer et al., 2000). Karst deposits usually represent local habitats (i.e., the remains are not transported beyond the life habitat of the fauna) and may be averaged over time intervals of 100 to 10,000 years (Behrensmeyer, 1988; Andrews, 1990, p. 93-95; Behrensmeyer and Hook, 1992). These deposits typically include both large and small fossil vertebrates and are especially important for the latter, which are less commonly preserved in other depositional contexts (Andrews and Evans, 1983; Andrews, 1990, p. 1; Fernández-Jalvo and Andrews, 1992).

In Brazil, following the pioneer work of Peter Wilhelm Lund (Lund, 1840), cave deposits provided a great deal of well-preserved fossil remains (Paula-Couto, 1953, p. 2633 ), and they have been continuously explored (Cartelle and Hartwig, 1996; Lessa et al., 1998; Salles et al., 1999; Santos et al., 2002). Although the Quaternary fossil record shows high abundance and diversity of small mammals, these have been mostly disregarded in paleontological works in Brazil (Salles et al., 1999). Stratigraphic control has often been poor, and taphonomic and geochronologic studies are scarce (Auler et al., 2006). Concerning their age, Brazilian cave deposits are loosely dated as late Quaternary. Some authors (e.g., Cartelle, 1995) consider their faunas as contemporaneous and representative of the PleistoceneHolocene transition. Doubts about the synchronicity and age of these deposits have long been recognized (PaulaCouto, 1975) and are supported by the broad range of Useries dates reported for mammalian faunas of northeastern Brazilian caves (Auler et al., 2006). Moreover, recent work has produced Pleistocene records for living genera, as well as early Holocene ages for extinct taxa (Baffa et al., 2000; Neves and Piló, 2003; Auler et al., 2006, Hubbe et al., 2007).

The fossil remains studied here were collected during September 2001 from a karstic fissure known as Abismo Iguatemi. Along with the blocks of sediment containing the micro-remains, macrofossils were recovered from the bottom of the cave, but no stratigraphic or taphonomic information was recorded. The site was first explored in November 1999 by Ferreira and Karmann, (2002), who retrieved paleontological material, including remains of a 
ground sloth (Catonyx cuvieri), and the skull of a sabertooth cat (Smilodon populator). Postcranial elements possibly associated with that skull were described later (Castro and Langer, 2008).

\section{Study Area}

Abismo Iguatemi is located about $5 \mathrm{~km}$ southwest of the town of Apiaí, upper Ribeira River valley, São Paulo, Brazil (Fig. 1), in an area presently covered by ombrophilous dense (Mata Atlântica) and secondary forests (Kronka, 2005, p. 53). Many caves in the region were previously studied (Ameghino, 1907; Krone, 1950; PaulaCouto, 1954, 1973; Lino et al., 1979; Barros Barreto et al., 1982) and yielded mainly megafauna remains. The $15 \mathrm{~m}$ deep and $44 \mathrm{~m}$ long fissure is formed in the intensely folded rocks of the Açungui Group (Middle Proterozoic), which includes metamorphized dolomitic limestones intercalated with insoluble lithologies (Auler and Farrant, 1996). The deposits in the cave are mainly composed of black to reddish clay associated with larger clasts of limestone, filite, and calcite crusts. The poor sorting of the grains is probably related to water percolating through the fissure, as it is located in the middle of a gentle slope (Ferreira and Karmann, 2002). The present access to the cave is limited to a small vertical slot.

\section{Analyses AND Results}

The blocks of sediment were disintegrated in water and screen-washed using a $1 \mathrm{~mm}$ mesh. The recovered microremains are mainly fragmentary small vertebrate specimens ranging from a few millimeters to about $10 \mathrm{~cm}$ and are housed at Museu de Zoologia da Universidade de São Paulo. Several studies have demonstrated that a wide assortment of paleontological aspects, such as hydrodynamic sorting and preservational properties, are affected by the bone size (see Kowalewski and Hoffmeister, 2003). To avoid any bias related to the choice of discrete size ranges, the total fraction of bioclasts was analyzed. This presumably provides a more accurate interpretation of the fossil assemblage by sampling a greater spectrum of organisms (Rodrigues and Simões, 2004). The fragmentation and weathering (polishing and abrasion) of the fossils restricted their taxonomic assignments. Out of 4,534 recovered remains, 3\% were taxonomically identified at generic or specific level, $13 \%$ at suprageneric levels (minimally class), and $41 \%$ were only anatomically identified. Besides mammalian specimens, which represented $74 \%$ of the taxonomically identified sample, amphibian $(15 \%)$, reptilian $(6 \%)$, and avian $(5 \%)$ material was also collected.

\section{TAPHONOMic Aspects}

The taxonomically or anatomically identified mammal elements are mostly fragmented and not articulated, except for series of a maximum of three vertebrae of small, indeterminate mammals. Large forms include only Smilodon populator, Catonyx cuvieri, and Glyptodon clavipes, the remains of which exhibit similar weathering to the remains of the small taxa. The polished and abraded surfaces, mostly concentrated on the extremities of the fossils, may be related to either pluvial transport into or reworking inside the cave. Spatial distribution of the bones is scattered, except for the remains of Smilodon populator and Cebus cf. C. nigritus, which were clustered, probably representing the disarticulation of single skeletons. Bone fractures are straight and uniform, a pattern frequently related to completely or partially mineralized material (Holz and Simões, 2002, p. 73), which also suggests reworking.

The analyzed remains include 559 isolated teeth and 226 disarticulated vertebrae, which make a 2.47 ratio, consistent with fluvial transportation (Behrensmeyer and Dechant-Boaz, 1980). In this case, however, the small proportion of vertebrae may be related to depletion during their transport by rain runoff or reworking inside the cave. Hydraulic sorting was estimated by Voorhies Groups (Voorhies, 1969; Behrensmeyer, 1975), which classify bioclasts based on their dispersal trends. The allochthonous nature of the Abismo Iguatemi fossil assemblage is corroborated by the minor proportion of skeletal elements that tend to resist transportation, i.e., Group III, and the prevalence of Groups I and II (Table 1), composed of, respectively, remains that tend to be promptly removed from carcasses and elements removed gradually. Accordingly, it is assumed that most of the fossilized mammalian fauna lived in habitats in the vicinity of the cave, not inside it.

Given the nearly vertical entrance of Abismo Iguatemi, likely sources of bioclasts are (1) the fall of animals into the natural trap, (2) floating carcasses or (3) isolated specimens of animals that died upslope and were washed into the cave, and (4) the animals that lived and died inside the cave. Based on the discussion above, we believe that most of the recovered material entered the cave from the third source, although the clustered remains with non-overlapping elements were probably accumulated by the first or second sources. The relatively scarce chiropteran record suggests that bats did not inhabit the cave; otherwise this group would be represented by more complete fossils and would be more abundant.

\section{Counting Individuals: MNI Versus NISP Indices}

Relative abundance of taxa in fossil assemblages is frequently estimated by the determination of the number of individuals per taxon. The numerical results may vary markedly with the adoption of different counting criteria, but the context of bone accumulation provides the required basis to decide which is more appropriate (Badgley, 1986). If the material is widely dispersed due to extensive transportation and accumulated as isolated specimens, it 


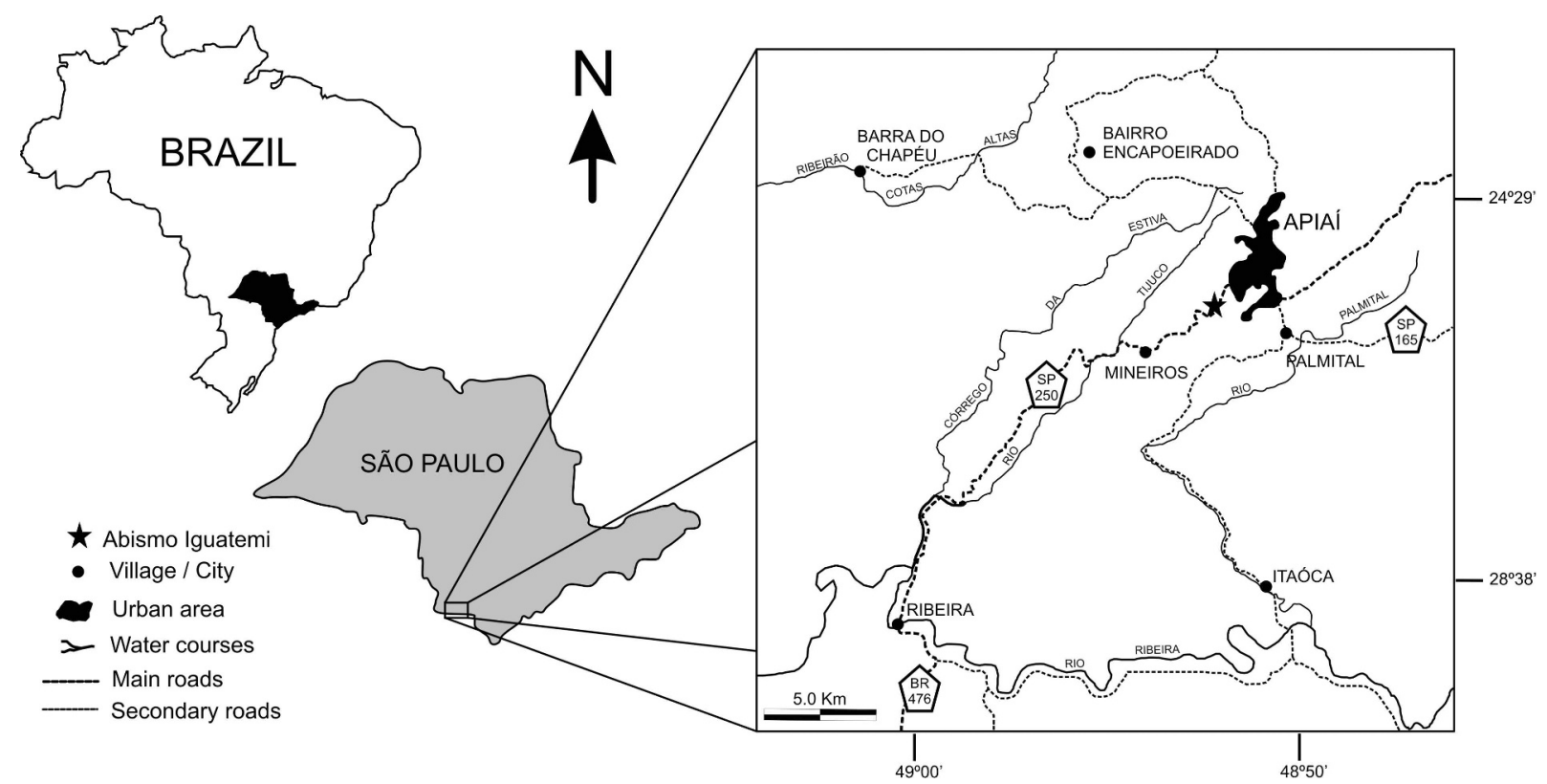

Figure 1. Location of Abismo Iguatemi, São Paulo, Brazil.

Table 1. Number and relative abundance of skeletal elements per Voorhies Groups.

\begin{tabular}{|c|c|c|c|c|}
\hline \multirow[b]{2}{*}{ Skeletal Elements } & \multicolumn{3}{|c|}{ Number of Elements } & \multirow[b]{2}{*}{$\begin{array}{c}\text { Relative } \\
\text { Abundance (\%) }\end{array}$} \\
\hline & $\begin{array}{l}\text { Taxonomically } \\
\text { Identified }\end{array}$ & $\begin{array}{c}\text { Anatomically Identified } \\
\text { Only }\end{array}$ & Total & \\
\hline \multicolumn{5}{|l|}{ Group I } \\
\hline Astragalus & 1 & 16 & 17 & 0.67 \\
\hline Calcaneus & 0 & 23 & 23 & 0.91 \\
\hline Phalanges & 0 & 130 & 130 & 5.14 \\
\hline Ribs & 11 & 73 & 84 & 3.32 \\
\hline Vertebrae & 2 & 224 & 226 & 8.94 \\
\hline Isolated teeth & 527 & 32 & 559 & 22.10 \\
\hline Scapula & 0 & 7 & 7 & 0.28 \\
\hline Osteoderm & 3 & 0 & 3 & 0.12 \\
\hline Subtotal & 544 & 505 & 1049 & 41.48 \\
\hline \multicolumn{5}{|l|}{ Group II } \\
\hline Femora & 1 & 107 & 108 & 4.27 \\
\hline Humeri & 0 & 36 & 36 & 1.42 \\
\hline Ulnae & 1 & 24 & 25 & 0.99 \\
\hline Pelvis & 2 & 16 & 18 & 0.71 \\
\hline Radius & 1 & 0 & 1 & 0.04 \\
\hline Other long bones & 27 & 1161 & 1188 & 46.98 \\
\hline Subtotal & 32 & 1344 & 1376 & 54.41 \\
\hline \multicolumn{5}{|l|}{ Group III } \\
\hline Mandible & 64 & 0 & 64 & 2.53 \\
\hline Maxillae & 34 & 0 & 34 & 1.34 \\
\hline Skull & 1 & 5 & 6 & 0.24 \\
\hline Subtotal & 99 & 5 & 104 & 4.11 \\
\hline Total & 675 & 1854 & 2529 & 100 \\
\hline
\end{tabular}


is suitable to infer the number of individuals based on the number of specimens of each taxon (NISP index). This method assumes that the probability of association (i.e., that more than one skeletal element of a fossil assemblage belongs to the same individual) is zero. In contrast, determining the minimum number of individuals represented by multiple skeletal elements (MNI index) assumes a high probability of association and is appropriate for material that accumulated in articulated form and was later disarticulated by reworking, as occurs in natural traps (Badgley, 1986). Both approaches were tested here in an attempt to infer which better fits the studied case. Tooth locus determination was ambiguous for the molars of some rodents, especially for teeth considerably weathered on the occlusal surface that probably belonged to senile individuals. Accordingly, tooth locus was not used to determine MNI for Rodentia, so this index may be an underestimate for the group.

A total of 35 taxa were recorded in Abismo Iguatemi (Figs. 2 and 3), four of which are extinct, and the number of individuals per taxon estimated by both NISP and MNI indices is provided in Table 2. Badgley (1986) suggested adopting the MNI index for natural-trap deposits because their fossil assemblages include articulated material, clustered skeletal elements of the same taxon, and relatively little bone damage. However, fossils from Abismo Iguatemi do not fit this combination of features: articulated sequences are rare, most material has a scattered spatial distribution and is polished or abraded. Indeed, the choice of the counting method must be based upon underlying assumptions on the probability of skeletal association, given the accumulation processes inferred from the taphonomic characteristics of the fossil assemblage. In Abismo Iguatemi, the MNI index is preferable if bioclastic sources 1, 2, or 4 (see above) occurred, while the NISP index is appropriate if mode 3 was the case. Relative abundance, using either NISP or MNI indices (Fig. 4), reveals that rodents are the most abundant mammalian group recovered from Abismo Iguatemi, as also seen in the living fauna of the area (Silva, 2001).

\section{Comparing Sites}

The mammalian fauna of Abismo Iguatemi was compared with that of several other Brazilian Quaternary deposits and with the present diversity of different modern habitats (Table 3). Because species diversity consists of richness (the number of species) and evenness (or equitability) of species abundances, quantitative coefficients of similarity, i.e., Bray-Curtis and Morisita-Horn indexes, are considered more accurate than qualitative indexes (Magurran, 1988, p. 95-96). However, because not all of the faunas with which Abismo Iguatemi was compared include abundance, Jaccard's qualitative index was adopted. This is based on the number of species in each sample, which were counted and weighted equally. Ten faunal lists were used for comparison, including five
Quaternary fossils sites and five extant ecosystems. The latter include three areas of ombrophilous dense forest (Vaz, 2005), two of which are near Abismo Iguatemi (Pianca, 2001; Instituto Ambiental do Paraná, 2002, p. VI 22-27), as well as two savannah areas, one in the state of São Paulo (Lyra-Jorge and Pivello, 2005; Talamoni, 1996) and another in Central Brazil (Passamani, 2004). Out of the fossil assemblages used for comparison, three are located in the municipality of Iporanga, near Abismo Iguatemi (Ameghino, 1907; Paula-Couto, 1973; Lino et al., 1979; Barros Barreto et al., 1982), and two in areas presently covered by savannah in Central Brazil (SouzaCunha and Guimarães, 1982; Salles et al., 1999). For comparison to the extant faunistic inventories, extinct taxa of Abismo Iguatemi (Smilodon populator, Catonyx cuvieri, and Glyptodon clavipes) were not considered. In order to match the restricted collection efforts of some inventories (e.g., non-flying mammals or exclusively small mammals), some taxa recorded in Abismo Iguatemi were excluded from the comparisons. In addition, because various faunal lists were uncertain about identification to species, the comparisons were conducted at the generic level.

Although generally low, Jaccard indices are higher for comparisons with living faunas (30\% similarity on average) than with other fossil assemblages (17\% on average). They are never above to $36 \%$ and $25 \%$, respectively. Comparisons to faunas of either dense forest or savannah are similar. This may be a consequence either of timeaveraging in Abismo Iguatemi or many taxa with wide geographic distributions, living in different phytophysiognomies (see below).

\section{Discussion And Conclusions}

Regardless of the difficulties associated with the study of fossil assemblages composed of fragmentary remains, the attempt to extract additional information from Abismo Iguatemi revealed that skeletal remains probably entered this cave partially articulated (trapped or transported by rain runoff as partial or complete decaying carcasses) as well as in the form of isolated elements. The former was probably the case for the clustered elements of Smilodon populator, Catonyx cuvieri, and Cebus cf. C. nigritus. For the other taxa, the deposition of isolated specimens by transport was presumably more frequent. In this case, NISP values seem to better fit the faunistic composition of the studied deposit.

Although Brazilian cave deposits usually have been assigned to the Pleistocene-Holocene boundary, new radiometric dates challenge this assumption, suggesting a time span encompassing much of the upper Pleistocene and early Holocene (Auler et al., 2006; Hubbe et al., 2007). Specimens of Catonyx cuvieri and Smilodon populator from Abismo Iguatemi provided ${ }^{14} \mathrm{C}$ AMS ages of 10,800 (BETA 230974) and 14,580 (BETA 183566) years BP respectively (A. Hubbe, pers. comm., 2008), confirming a 

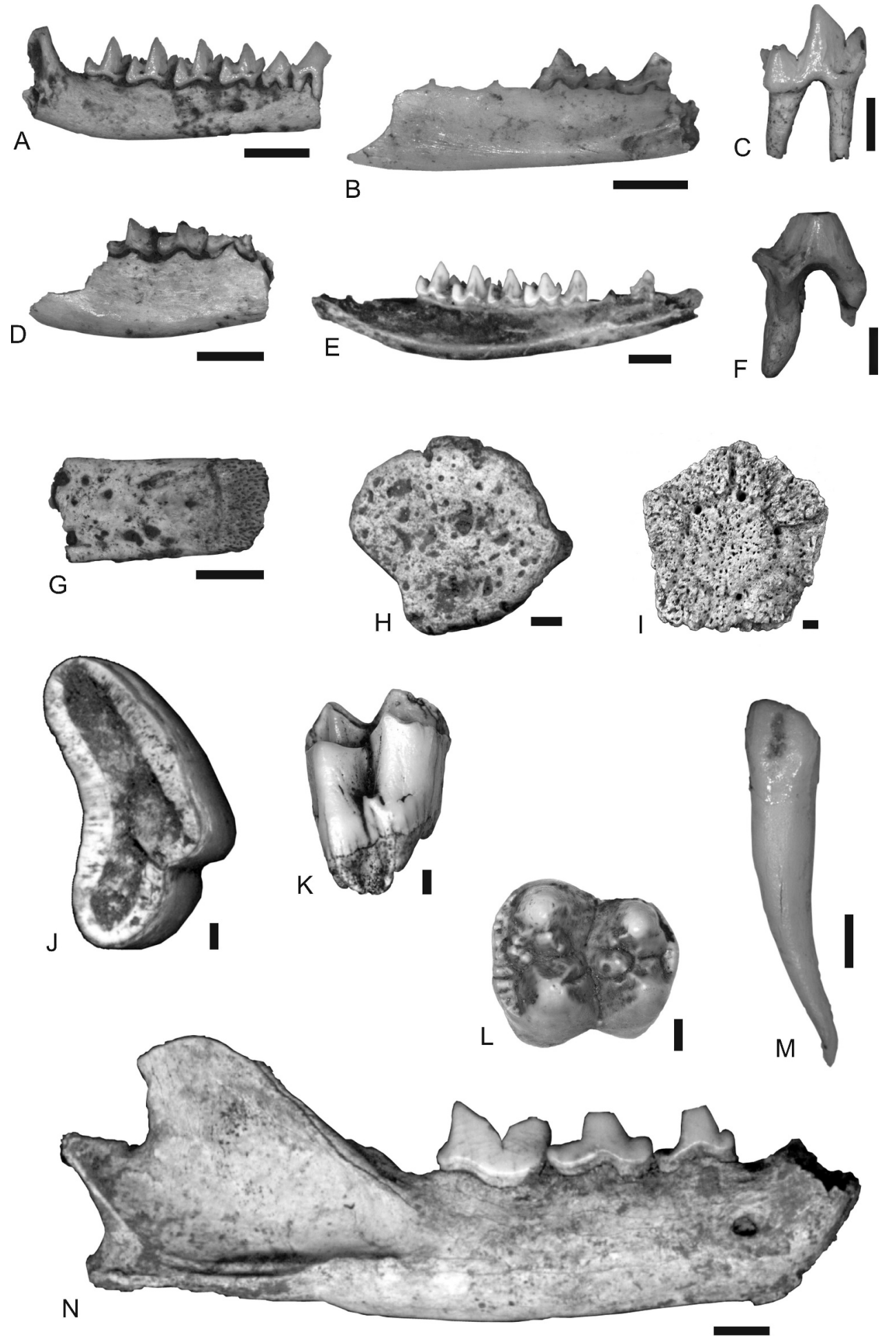

Figure 2. Marsupials, xenarthrans, artiodactylans, and carnivorans from Abismo Iguatemi. A. Cryptonanus sp., left mandibular fragment in lingual view; B. Gracilinanus sp., right mandibular fragment in labial view; C. Philander sp., probable $\mathrm{M}_{2}$ in labial view; D. Monodelphis sp., right mandibular fragment in labial view; E. Metachirus nudicaudatus, right mandibular fragment in labial view; F. Didelphis aurita, probable right $\mathbf{P}^{2}$ in lingual view; G. Dasypodidae indet., osteoderm fragment in external view; H. Glyptodontidae indet., osteoderm fragment in external view; I. Glyptodon clavipes, osteoderm in external view; J. Catonyx cuvieri, right $\mathrm{M}^{2}$ in occlusal view; K. Mazama gouazoubira, molar in labial view; L. Pecari tajacu; probable right $\mathrm{M}^{2}$ in occlusal view; M. Cerdocyon thous, lower left incisor in labial view; N. Leopardus wiedii, left mandibular ramus in labial view. Scale bars $=2 \mathrm{~mm}(\mathrm{~A}-\mathrm{D}, \mathrm{F}, \mathrm{G}, \mathrm{K}-\mathrm{M}),=4 \mathrm{~mm}(\mathrm{E}, \mathrm{H}, \mathrm{I}, \mathrm{N})$. 

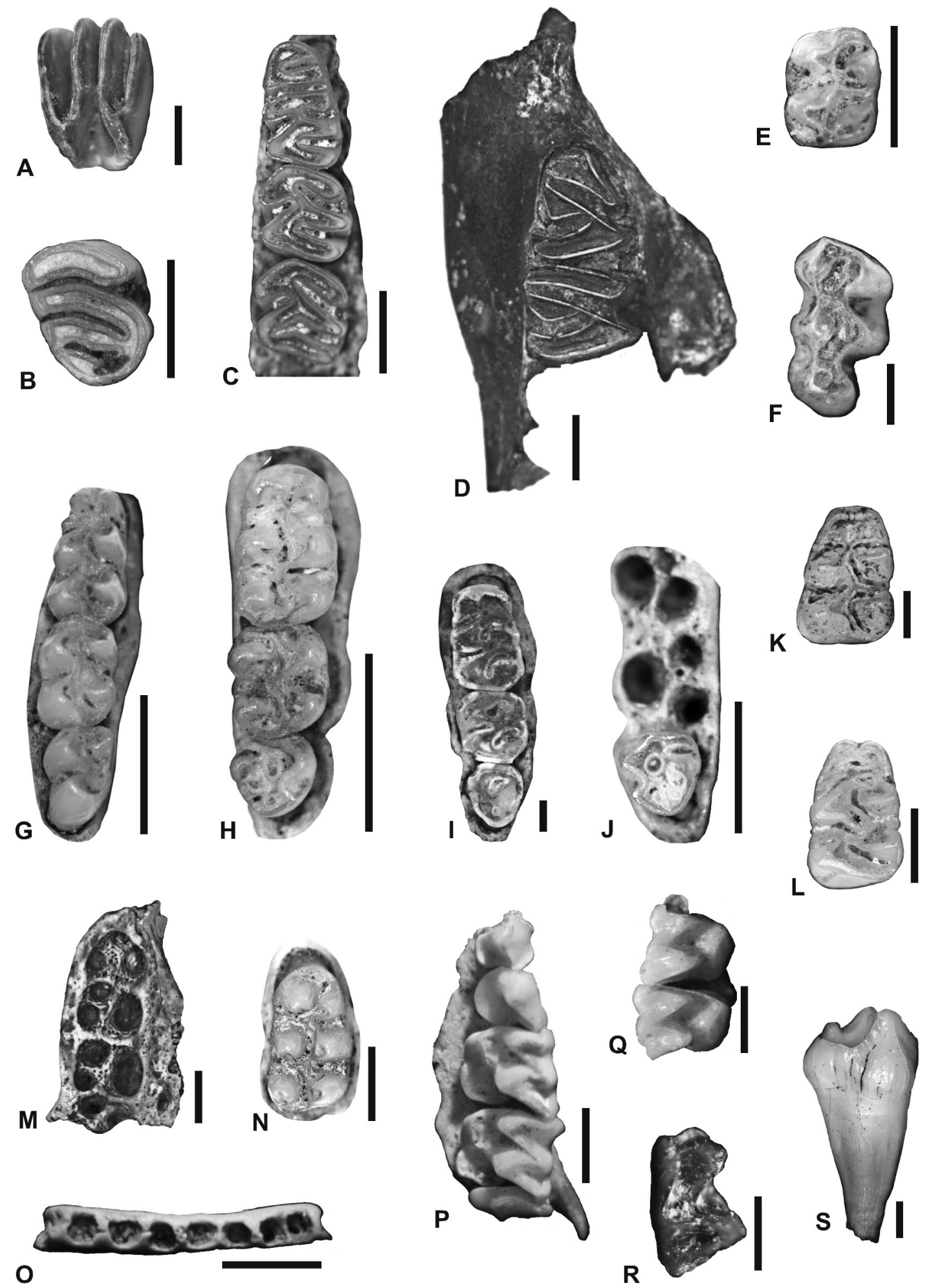

Figure 3. Rodents, bats, and primate from Abismo Iguatemi. A-R, occlusal views: A. Kannabateomys sp., molar fragment; B. Trinomys sp., molar; C. Phyllomys sp., left mandibular fragment; D. Cavia sp., left mandibular fragment; E. Oryzomys cf. O. capito, molar; F. Blarinomys breviceps, $\mathbf{M}^{\mathbf{1}}$; G. Akodon sp., left mandibular fragment; H. Oligoryzomys sp., right maxillar fragment; I. Oryzomys sp., left maxillar fragment; J. Calomys sp., left maxillar fragment; K. Oryzomys cf. O. angouya, left $\mathbf{M}_{1}$; L. Wilfredomys sp., $\mathbf{M}^{1}$; M. Sciurus aestuans, right maxillar fragment; N. Wilfredomys oenax, right $\mathbf{M}^{1}$; O. Carollia sp., right mandibular fragment; P. Mimon benettii, left maxillar fragment; Q. Molossus sp., right $\mathbf{M}^{1-2} ; \mathrm{R}$. Myotis sp., $\mathbf{M}^{3}$. S. Alouatta cf. A. fusca, probable left $\mathrm{M}_{1}$ in lingual view. Scale bars $=1 \mathrm{~mm}(\mathrm{E}-\mathrm{G}, \mathrm{K}, \mathrm{L}, \mathrm{Q}, \mathrm{R}) ;=2 \mathrm{~mm}(\mathrm{~A}-\mathrm{D}, \mathrm{H}-\mathrm{J}, \mathrm{M}-\mathrm{P}, \mathrm{S})$. 
Table 2. Identified taxa and numbers of individual according to NISP and MNI indexes.

\begin{tabular}{|c|c|c|}
\hline Taxon & NISP index & MNI index \\
\hline \multicolumn{3}{|l|}{ Marsupialia } \\
\hline Cryptonanus sp. & 1 & 1 \\
\hline Didelphis aurita & 1 & 1 \\
\hline Gracilinanus sp. & 2 & 2 \\
\hline Metachirus nudicaudatus & 2 & 2 \\
\hline Monodelphis sp. & 1 & 1 \\
\hline Philander sp. & 6 & 2 \\
\hline Subtotal & 13 & 9 \\
\hline \multicolumn{3}{|l|}{ Xenarthra } \\
\hline Dasypodidae indet. & 1 & 1 \\
\hline 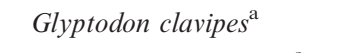 & 1 & 1 \\
\hline Glyptodontidae indet. $^{\mathrm{a}}$ & 1 & 1 \\
\hline Catonyx cuvieri $^{\mathrm{a}}$ & 17 & 1 \\
\hline Subtotal & 20 & 4 \\
\hline \multicolumn{3}{|l|}{ Carnivora } \\
\hline Cerdocyon thous & 1 & 1 \\
\hline Leopardus wiedii & 1 & 1 \\
\hline Smilodon populator ${ }^{\mathrm{a}}$ & 21 & 1 \\
\hline Subtotal & 23 & 3 \\
\hline \multicolumn{3}{|l|}{ Chiroptera } \\
\hline Molossus sp. & 2 & 1 \\
\hline Carollia sp. & 2 & 1 \\
\hline Mimon benettii & 6 & 2 \\
\hline Myotis sp. & 1 & 1 \\
\hline Subtotal & 11 & 5 \\
\hline \multicolumn{3}{|l|}{ Primates } \\
\hline Cebus cf. C. nigritus & 154 & 1 \\
\hline Alouatta $\mathrm{cf}$. A. fusca & 1 & 1 \\
\hline Subtotal & 155 & 2 \\
\hline \multicolumn{3}{|l|}{ Artiodactyla } \\
\hline Mazama gouazoubira & 1 & 1 \\
\hline Pecari tajacu & 1 & 1 \\
\hline Subtotal & 2 & 2 \\
\hline \multicolumn{3}{|l|}{ Rodentia } \\
\hline Kannabateomys sp. & 1 & 1 \\
\hline Phyllomys sp. & 57 & 7 \\
\hline Trinomys sp. & 16 & 2 \\
\hline Cavia sp. & 9 & 1 \\
\hline Akodon sp. & 4 & 1 \\
\hline Blarinomys breviceps & 1 & 1 \\
\hline Calomys sp. & 1 & 1 \\
\hline Oligoryzomys sp. & 3 & 2 \\
\hline Oryzomys sp. & 13 & 2 \\
\hline Oryzomys cf. O. angouya & 2 & 1 \\
\hline Oryzomys cf. O. capito & 1 & 1 \\
\hline Wilfredomys sp. & 1 & 1 \\
\hline Wilfredomys oenax & 1 & 1 \\
\hline Sciurus aestuans & 1 & 1 \\
\hline Subtotal & 111 & 23 \\
\hline Total & 335 & 48 \\
\hline
\end{tabular}

${ }^{a}$ Extinct Taxa.

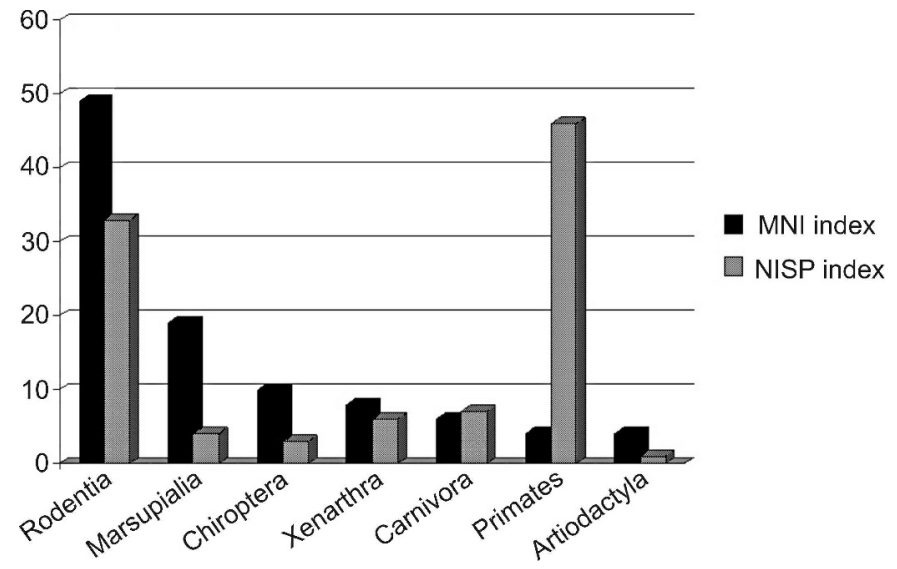

Figure 4. Relative abundance (\%) of individuals identified to generic or specific level using MNI and NISP indices.

late Pleistocene age for these extinct species. Because of the likelihood of time-averaging in the deposit (see below), it is possible that its extant taxa are Holocene in age. This could be confirmed by radiometric dates. In the absence of these, and considering the poor stratigraphic control during the collection of the Abismo Iguatemi fauna, a more accurate chronologic assignation is unfeasible.

Along with absolute dates and taphonomic signatures, paleoecological data can also be used to identify timeaveraging in Quaternary assemblages. Paleoenvironmental inferences are best based on the known habitat requirements of extant species, or on fossils with adaptations to particular environments (Auler et al., 2006). Almost half of the extant taxa recorded in Abismo Iguatemi are not informative for this sort of inference, because they occur over a wide geographic range, in both savannah and dense forested areas (Weksler et al., 1999; Wilson and Reeder, 2005, p. 6-7, 12-17, 412, 440-441, 501-517, 540, 578, 644, 656, 1106-1109, 1140-1143, 1552-1553; Voss et al., 2005). On the other hand, among the extinct taxa, Glyptodon clavipes and Catonyx cuvieri are usually considered opencountry herbivores (Vizcaíno and Bargo, 1998; Ubilla and Perea, 1999; Perez et al., 2000), possibly preyed upon by Smilodon populator, which is less confidently assigned to savannah habitats (Paula-Couto, 1979, p. 338-340; Kurtén and Werdelin, 1990). Small mammals are usually considered good proxies for climatic conditions (Avery, 1982), and some living taxa identified in the cave are endemic to ombrophilous dense forest (Mata Atlântica), e.g., Didelphis aurita (Silva, 2001), Blarinomys breviceps (Silva et al., 2003), Kannabateomys sp., Wilfredomys sp., Trinomys sp., and Phyllomys sp. (Leite, 2003, p. 101).

It is possible that all of the recovered taxa coexisted in a mosaic of savannah and moist habitats or, contrary to the currently accepted notion, that the extinct Glyptodon clavipes, Catonyx cuvieri, and Smilodon populator may have also inhabited forested areas, as has been inferred for other megafaunal elements in the Brazilian Amazon

Journal of Cave and Karst Studies, August 2011•89 
Table 3. Similarity indexes $\left(C_{\text {Jaccard }}\right)$ between mammalian fauna of Abismo Iguatemi and other faunal inventories. $N(A)$ Number of taxa considered in Abismo Iguatemi; N(B) Number of taxa considered in the other studies; N(AB) Number of taxa represented in both sites; $\mathrm{AI}$ is Abismo Iguatemi faunistic assemblage.

\begin{tabular}{|c|c|c|c|c|}
\hline Fauna Type & $\mathrm{N}(\mathrm{A})$ & $\mathrm{N}(\mathrm{B})$ & $\mathrm{N}(\mathrm{AB})$ & $\mathrm{C}_{\text {Jaccard }}$ \\
\hline \multicolumn{5}{|l|}{ Quaternary Fossils Assemblages } \\
\hline $\mathrm{AI} /$ Karstic caves, Iporanga, $\mathrm{SP}^{\mathrm{a}}$ & 29 & 15 & 4 & 0.10 \\
\hline AI/Abismo do Fóssil, Iporanga, SP $^{\mathrm{b}}$ & 29 & 21 & 10 & 0.25 \\
\hline AI/Abismo Ponta de Flecha, Iporanga, $\mathrm{SP}^{\mathrm{c}}$ & 29 & 17 & 5 & 0.12 \\
\hline AI/Caves in Serra da Mesa, $\mathrm{GO}^{\mathrm{d}}$ & 29 & 41 & 11 & 0.19 \\
\hline AI/Lapa Vermelha, $\mathrm{MG}^{\mathrm{e}}$ & 29 & 21 & 8 & 0.19 \\
\hline \multicolumn{5}{|l|}{ Living Faunas } \\
\hline AI/Parque do Zizo, São Miguel Arcanjo, SP $^{f}$ & 6 & 11 & 4 & 0.31 \\
\hline AI/Pedra Branca, Paraty, RJ ${ }^{\mathrm{g}}$ & 22 & 31 & 14 & 0.36 \\
\hline AI/Parque das Lauráceas, Adrianópolis, $\mathrm{PR}^{\mathrm{h}}$ & 26 & 31 & 10 & 0.21 \\
\hline AI/Vicinity of Palmas, $\mathrm{TO}^{\mathrm{i}}$ & 16 & 23 & 9 & 0.30 \\
\hline AI/Pé-de-Gigante and Jataí, Luís Antônio, SP & 22 & 36 & 14 & 0.32 \\
\hline
\end{tabular}

a Ameghino (1907) and further alterations by Paula-Couto (1973).

b Lino et al. (1979).

${ }^{c}$ Barros Barreto et al. (1982).

${ }^{\mathrm{d}}$ Salles et al. (1999).

e Souza-Cunha and Guimarães (1982).

${ }^{\mathrm{f}}$ Pianca (2000).

${ }^{\mathrm{g}}$ Vaz (2005).

${ }^{\text {h }}$ IAP (2002).

i Passamani (2004).

j Talamoni (1996), Lyra-Jorge and Pivello (2005).

(Rossetti et al., 2004; MacFadden, 2005). Otherwise, we suggest that the occurrence in Abismo Iguatemi of organisms interpreted as having different ecological requirements is related to time-averaging, instead of spatial averaging, because karstic deposits have minimum transport beyond the immediate paleocommunity habitat (Behrensmeyer and Hook, 1992). Indeed, this may be an example of an Environmentally Condensed Assemblage, where extended time-averaging allows finding specimens associated with different environments, of ecologically unrelated species, and with varied taphonomic signatures (Kowalewski, 1996). The existence of two typical faunistic groups (extinct open field or savannah and extant ombrophilous dense forest organisms) suggests that environmental changes occurred in the Holocene of South America, when the establishment of a more humid phase would have caused the expansion of landscapes with denser vegetation and the extinction of the megafauna that inhabited open physiognomies (see de Vivo and Carmingnotto, 2004). Some of the discussed uncertainties could be resolved with further studies; the Holocene age of the extant taxa could be confirmed by radiometric dating, while the habitat requirements of the herbivores could be determined by stable isotope methods.

\section{ACKNOWLEDGEMENTS}

We gratefully acknowledge Fundação de Amparo à Pesquisa do Estado de São Paulo for financial support
(FAPESP 04/10573-9); the researchers of Museu de Zoologia da Universidade de São Paulo who collected the fossil remains at Abismo Iguatemi; Dr. Hussam El Dine Zaher and Dr. Mario de Vivo (MZUSP) for the permission to study the material under their care; MSc. Alex Hubbe for information on specimens datings; Dr. Gilson Ximenes, Dr. Rogério Rossi, and Dra. Maria Paula Fracasso for helping with the micromammals assignation.

\section{REFERENCES}

Ameghino, F., 1907, Notas sobre una pequeña colección de huesos de mamíferos procedentes de las grutas calcarías de Iporanga, en el estado de São Paulo, Brazil: Revista do Museu Paulista, v. 3, p. $59-124$

Andrews, P.J., and Evans, E.M.N., 1983, Small mammal bone accumulations produced by mammalian carnivores: Paleobiology, v. 9, no. 3 , p. 289-307.

Andrews, P.J., 1990, Owls, caves and fossils: predation, preservation and accumulation of small mammal bones in caves, with an analysis of the Pleistocene cave faunas from Westbury-sub-Mendip, Somerset, UK: London, British Museum (Natural History), viii, 231 p.

Auler, A.S., and Farrant, A.R., 1996, A brief introduction to karst and caves in Brazil: Proceedings of the University of Bristol Spelaeological Society, v. 20, p. $187-200$.

Auler, A.S., Pilo, L.B., Smart, P.L., Wang, X.F., Hoffmann, D., Richards, D.A., Edwards, R.L., Neves, W.A., and Cheng, H., 2006, U-series dating and taphonomy of Quaternary vertebrates from Brazilian caves: Palaeogeography Palaeoclimatology Palaeoecology, v. 240, no. 3-4, p. 508-522, doi: 10.1016/j.palaeo.2006.03.002.

Avery, D.M., 1982, Micromammals as palaeoenvironmental indicators and an interpretation of the Late Quaternary in the southern Cape Province, South Africa: Annals of the South African Museum, v. 85, no. 2 , p. $183-374$. 
Badgley, C., 1986, Counting individuals in mammalian fossil assemblages from fluvial environments: Palaios, v. 1, no. 3, p. 328-338.

Baffa, O., Brunetti, A., Karmann, I., and Neto, C.M.D., 2000, ESR dating of a toxodon tooth from a Brazilian karstic cave: Applied Radiation and Isotopes, v. 52, no. 5, p. 1345-1349.

Barros Barreto, C.N.G., De Blasis, P.A.D., Dias-Neto, C.M., Karmann, I., Lino, C.F., and Robrahn, E.M., 1982, Abismo Ponta de Flecha: um projeto arqueológico, paleontológico e geológico no médio Ribeira de Iguape, São Paulo: Revista de Pré-História, v. 3, p. 195-215.

Behrensmeyer, A.K., 1988, Vertebrate preservation in fluvial channels: Palaeogeography Palaeoclimatology Palaeoecology, v. 63, no. 1-3, p. 183-199.

Behrensmeyer, A.K., and Dechant-Boaz, D.E., 1980, The recent bones of Amboseli Park, Kenya, in relation to East African paleoecology, in Behrensmeyer, A.K., and Hill, A.P., eds., Fossils in the Making, Chicago, University of Chicago Press, Prehistoric Archeology and Ecology series, p. 77-92.

Behrensmeyer, A.K., and Hook, R.W., 1992, Paleoenvironmental contexts and taphonomic modes, in Behrensmeyer, A.K., Damuth, J.D., DiMichelle, W.A., Potts, R., Sues, H.-D., and Wing, S.L., eds., Terrestrial Ecosystems Through Time: Evolutionary Paleoecology of Terrestrial Plants and Animals, Chicago, University of Chicago Press, p. $15-136$.

Behrensmeyer, A.K., and Kidwell, S.M., 1985, Taphonomy's contributions to paleobiology: Paleobiology, v. 11, no. 1, p. 105-119.

Behrensmeyer, A.K., Kidwell, S.M., and Gastaldo, R.A., 2000, Taphonomy and paleobiology: Paleobiology, v. 26, no. 4, p. 103-147.

Cartelle, C., 1995, A fauna local de mamíferos pleistocênicos da Toca da Boa Vista (Laje dos Negros, BA) [Thesis]: Belo Horizonte, Universidade Federal de Minas Gerais, $131 \mathrm{p}$.

Cartelle, C., and Hartwig, W.C., 1996, A new extinct primate among the Pleistocene megafauna of Bahia, Brazil: Proceedings of the National Academy of Sciences of the United States of America, v. 93, no. 13, p. 6405-6409.

Castro, M.C., and Langer, M.C., 2008, New postcranial remains of Smilodon populator Lund, 1842 from south-central Brazil: Revista Brasileira de Paleontologia, v. 11, no. 3, p. 199-206, doi: 10.4072/ rbp.2008.3.06

de Vivo, M., and Carmignotto, A.P., 2004, Holocene vegetation change and the mammal faunas of South America and Africa: Journal of Biogeography, v. 31 , no. 6 , p. 943-957, doi: 10.1111/j.13652699.2004.01068.x.

Fernández-Jalvo, Y., and Andrews, P., 1992, Small mammal taphonomy of Gran Dolina, Atapuerca (Burgos) Spain: Journal of Archaeological Science, v. 19 , no. 4, p. 407-428.

Ferreira, N.B., and Karmann, I., 2002, Descobertas paleontológicas na região de Apiaí-SP: Boletim Informativo Geovisão, v. 10, p. 7-8.

Holz, M., and Simões, M.G., 2002, Elementos fundamentais de tafonomia: Porto Alegre, Editora da Universidade-UFRGS, $231 \mathrm{p}$.

Hubbe, A., Hubbe, M., and Neves, W., 2007, Early holocene survival of megafauna in South America: Journal of Biogeography, v. 34, no. 9, p. 1642-1646, doi: 10.1111/j.1365-2699.2007.01744.x.

Instituto Ambiental do Paraná, 2002, Plano de manejo do Parque Estadual das Lauráceas: Curitiba, Secretaria de Estado do Meio Ambiente e Recursos Hídricos, 348 p

Kowalewski, M., 1996, Time-averaging, overcompleteness, and the geological record: Journal of Geology, v. 104, no. 3, p. 317-326.

Kowalewski, M., and Hoffmeister, A.P., 2003, Sieves and fossils: Effects of mesh size on paleontological patterns: Palaios, v. 18 , no. 4-5, p. 460-469, doi: 10.1086/629827.

Krone, R., 1950, As grutas calcárias do Vale do rio Ribeira de Iguape: O Instituto Geográfico e Geológico, v. 8, p. 248-297. (Reprint from Arquivos do Museu Nacional, 1909, Rio de Janeiro.)

Kronka, F.J.N., ed., 2005, Inventário florestal da vegetação natural do estado de São Paulo: São Paulo, Imprensa Oficial, 200 p.

Kurtén, B., and Werdelin, L., 1990, Relationships between North and South American Smilodon: Journal of Vertebrate Paleontology, v. 10, no. 2, p. 158-169, doi: 10.1080/02724634.1990.10011804.

Leite, Y.L.R., 2003, Evolution and systematics of the Atlantic tree rats, genus Phyllomys (Rodentia, Echimyidae), with description of two new species: University of California Publications in Zoology 132, 118 p.
Lessa, G., Cartelle, C., Faria, H.D., and Gonçalves, P.R., 1998, Novos achados de mamíferos carnívoros do Pleistoceno final-Holoceno em grutas calcárias do estado da Bahia: Acta Geologica Leopoldensia, v. 21, p. $157-169$.

Lino, C.F., Dias-Neto, C.M., Trajano, E., Gusso, G.L.N., Karmann, I., and Rodrigues, R., 1979, Paleontologia do Vale do Ribeiraexploração I, Abismo do Fóssil (SP-145): Resultados parciais, in Proceedings, II Simpósio Regional de Geologia: Rio Claro, p. $257-268$

Lund, P.W., 1840, View of the fauna of Brazil previous to the last geological revolution [translated from Danish original (1938) by W. Bilton]: Magazine of Natural History, v. 4, p. 1-8, 49-57, 105-112, 153-161, 207-213, 251-259, 307-317, 373-389.

Lyra-Jorge, M.C., and Pivello, V.R., 2005, Mamíferos, in Pivello, V.R., and Varanda, E.M., eds., O Cerrado Pé-de-Gigante (Parque Estadual de Vassununga, São Paulo): Ecologia e Conservação, São Paulo, Secretaria do Meio Ambiente, p. 133-148.

MacFadden, B.J., 2005, Diet and habitat of toxodont megaherbivores (Mammalia, Notoungulata) from the late Quaternary of South and Central America: Quaternary Research, v. 64, no. 2, p. 113-124.

Magurran, A.E., 1988, Ecology diversity and its measurement: Princeton, Princeton University Press, $179 \mathrm{p}$.

Neves, W.A., and Piló, L.B., 2003, Solving Lund's dilemma: new AMS dates confirm that humans and megafauna coexisted at Lagoa Santa: Current Research in the Pleistocene, v. 20, p. 57-60.

Passamani, M., 2004, Levantamento de pequenos mamíferos nãovoadores da região central do Tocantins: Humanitas, Revista do Centro Universitário Luterano de Palmas, v. 4-6, p. 55-60.

Paula-Couto, C., 1953, Paleontologia brasileira: mamíferos: Rio de Janeiro, Instituto Nacional do Livro, $516 \mathrm{p}$.

Paula-Couto, C., 1954, Megatérios intertropicais do Pleistoceno: Anais da Academia Brasileira de Ciências, v. 26, p. 447-463.

Paula-Couto, C., 1973, Edentados fósseis de São Paulo: Anais da Academia Brasileira de Ciências, v. 45, p. 261-275.

Paula-Couto, C., 1975, Mamíferos fósseis do Quaternário do sudeste brasileiro: Boletim Paranaense de Geociências, v. 33, p. 89-132.

Paula-Couto, C., 1979, Tratado de Paleomastozoologia: Rio de Janeiro, Academia Brasileira de Ciências, 590 p.

Perez, L.M., Scillato-Yané, G.J., and Vizcaíno, S.F., 2000, Morphofunctional analysis of the hyoid apparatus of Glyptodon cf. clavipes Owen (Cingulata : Glyptodontidae): Ameghiniana, v. 37, no. 3, p. $293-$ 299.

Pianca, C.C., 2001, Levantamento de mamíferos e de sua caça em uma área preservada de mata atlântica no sudeste de São Paulo: Pontifícia Universidade de São Paulo, 45 p.

Rodrigues, S.C., and Simões, M.G., 2004, Taphonomy of brachiopod shells from the Ubatuba Bay, Northern of São Paulo coast: can methodological decisions mask the (paleo)environmental inferences?, in Proceedings, Congresso Brasileiro de Geologia, XLII. Araxá, Sociedade Brasileira de Geologia, p. 904.

Rossetti, D.F., de Toledo, P.M., Moraes-Santos, H.M., and Santos, A.E.D., 2004, Reconstructing habitats in central Amazonia using megafauna, sedimentology, radiocarbon, and isotope analyses: Quaternary Research, v. 61, no. 3, p. 289-300.

Salles, L.O., Carvalho, G.S., Weksler, M., Sicuro, F.L., Abreu, F., Camardella, A.R., Guedes, P.G., Avilla, L.S., Abrantes, E.A.P., Sahate, V., and Costa, I.S.A., 1999, Mammals from the Quaternary of Serra da Mesa (Goiás, Brazil): Publicações Avulsas do Museu Nacional, v. 78, p. 1-15.

Santos, M.F.C.F., Lima-Filho, F.P., and Bergqvist, L.P., 2002, Fósseis pleistocênicos da Ravina do Leon, Lajedo de Soledade, Apodi/RN: Revista de Geologia, v. 15, p. 23-29.

Silva, C.R., 2001, Riqueza e diversidade de mamíferos não-voadores em um mosaico formado por plantios de Eucalyptus saligna e remanescentes de Floresta Atlântica no município de Pilar do Sul-SP [M.Sc. Thesis], Piracicaba, Universidade de São Paulo, 81 p.

Silva, F.M., Barreto, A.M.F., Sá, F.B., and Silva, A.C.L., 2003, Levantamento das ocorrências de fósseis de megafauna pleistocênica do estado de Pernambuco: Paleontologia em Destaque, v. 4, p. 53-54.

Souza-Cunha, F.L., and Guimarães, M.L., 1982, A fauna sub-recente de vertebrados do "Grande Abrigo da Lapa Vermelha Emperaire (P.L.)" de Pedro Leopoldo, estado de Minas Gerais: Revista do Museu Paulista, v. 28, p. 235-272. 
Sutcliffe, A.J., 1970, A section of an imaginary bone cave: Studies in Speleology, v. 2, no. 2, p. 79-80.

Talamoni, S.A., 1996, Ecologia de uma comunidade de pequenos mamíferos da Estação Ecológica de Jataí, Município de Luís Antônio-SP [Ph.D. Thesis], São Carlos, Universidade Federal de São Carlos, 173 p.

Ubilla, M., and Perea, D., 1999, Quaternary vertebrates of Uruguay: a biostratigraphic, biogeographic and climatic overview, in Tonni, E.P., and Cione, A.L., eds., Quaternary Vertebrate Paleontology in Southern South America, Leiden, the Netherlands, Balkema, Quaternary of South America and Antartic Peninsula 12, p. 75-90.

Vaz, S.M., 2005, Mamíferos coletados em Pedra Branca, município de Paraty, Rio de Janeiro, Brasil: Revista Brasileira de Zoologia, v. 22, no. 4, p. 1164-1169, doi: 10.1590/S0101-81752005000400051.

Vizcaíno, S.F., and Bargo, M.S., 1998, The masticatory apparatus of the armadillo Eutatus (Mammalia, Cingulata) and some allied genera: paleobiology and evolution: Paleobiology, v. 24, no. 3, p. 371-383.
Voorhies, M.R., 1969, Taphonomy and Population Dynamics of an Early Pliocene Vertebrate Fauna, Knox, County, Nebraska: Laramie, University of Wyoming, Contributions to Geology special paper 1, $69 \mathrm{p}$.

Voss, R.S., Lunde, D.P., and Jansa, S.A., 2005, On the Contents of Gracilinanus Gardner and Creighton, 1989, with the Description of a Previously Unrecognized Clade of Small Didelphid Marsupials, New York, American Museum of Natural History, Novitates no. 3482, $34 \mathrm{p}$.

Weksler, M., Geise, L., and Cerqueira, R., 1999, A new species of Oryzomys (Rodentia, Sigmodontinae) from southeast Brazil, with comments on the classifications of $O$. capito species group: Zoological Journal of the Linnean Society, v. 125, p. 445-462, doi: 10.1111/ j.1096-3642.1999.tb00600.x.

Wilson, D.E., and Reeder, D.M., 2005, Mammal Species of the World: A Taxonomic and Geographic Reference, 3rd edition: Baltimore, Johns Hopkins University Press, 2,142 p. 